\title{
KOMPOS DAN \\ PUPUK CAIR LIMBAH SAWIT UNTUK NUTRISI TANAMAN GAHARU (Aquilaria malaccensis)
}

\author{
Iriyawati $^{1}$, Hening Widowati ${ }^{2}$, Agus Sutanto ${ }^{3}$ \\ ${ }^{1}$ SMAN 1 Bangunrejo, ${ }^{2,3}$ Pascasarjana Universitas Muhammadiyah Metro \\ 1iriyawati28@gmail.com , ${ }^{2}$ hwummetro@gmail.com, ${ }^{3}$ sutanto11@gmail.com3-mail
}

\begin{abstract}
Abstrak: Tujuan dari penelitian ini adalah untuk mengembangkan aspek teoritis mengenai kandungan limbah cair dan padat pabrik kelapa sawit dan pengaruhnya terhadap pertumbuhan tanaman gaharu. Salah satu komoditas yang sangat menjanjikan dalam dunia industri adalah minyak goreng, maka perkebunan serta pabrik pengolahan sawit banyak berkembang di Indonesia. Hasil samping dari pabrik sawit adalah limbah sawit. Dari hasil studi literatur diketahui bahwa limbah kelapa sawit memilikim karakteristik antara lain pH 4,0-6,0, BOD 20.000 mg/l - $60.000 \mathrm{mg} / \mathrm{l}$, COD $40.000 \mathrm{mg} / 1$ - $12.000 \mathrm{mg} / \mathrm{l}$, N $500 \mathrm{mg} / \mathrm{l}$ - $900 \mathrm{mg} / \mathrm{l}$, P dari $90 \mathrm{mg} / \mathrm{l}$ - $140 \mathrm{mg} / \mathrm{l}$, K dari 260 $\mathrm{mg} / \mathrm{l}$ - $400 \mathrm{mg} / \mathrm{l}$, Ca dari $1.000 \mathrm{mg} / \mathrm{l}-2.000 \mathrm{mg} / \mathrm{l}$ dan $\mathrm{Mg}$ dari $250 \mathrm{mg} / \mathrm{l}$ - $350 \mathrm{mg} / \mathrm{l}$. banyak jurnal penelitian yang mengkaji mengenai kandungan limbah sawit yang kesemua jurnal meyatakan bahwa limbah sawit megandung unsur makro yang diperlukan oleh tumbuhan untuk tumbuh dan berkembang. Metode yang dilakukan adalah dengan studi Pustaka atau kajian pustaka dari sumber sumber yang relevan dan dapat dipertanggungjawabkan keilmiahannya sehingga mendapatkan data yang valid dan menjadi dasar dari suatu penelitian baru. kesimpulan dari penelitian ini adalah kompos dan pupuk cair organic dari limbah sawit memiliki kandungan unsur hara yang diperlukan untuk pertumbuhan tanaman termasuk tanaman gaharu yang saat ini setatusnya sebagai tumbuhan langka.
\end{abstract}

Kata kunci: gaharu, pupuk cair limbah sawit, pupuk kompos limbah sawit

\begin{abstract}
The purpose of this study was to develop a theoretical aspect regarding the content of liquid and solid waste from a palm oil mill and its effect on the growth of agarwood plants. One of the most promising commodities in the industrial world is cooking oil, so palm oil as a CPO-producing plant is widely developed in Indonesia. Apart from being a producer of CPO, palm oil also has other roles or benefits. From the results of the literature study, it is known that palm oil waste has characteristics, including $\mathrm{pH}$ 4.0-6.0, BOD 20,000 mg/l - 60,000 mg/l, COD 40,000 mg/l - 12,000 mg/l, $\mathrm{N} 500 \mathrm{mg} / \mathrm{l}$ $900 \mathrm{mg} / \mathrm{l}, \mathrm{P}$ from $90 \mathrm{mg} / \mathrm{l}-140 \mathrm{mg} / \mathrm{l}, \mathrm{K}$ from $260 \mathrm{mg} / \mathrm{l}-400 \mathrm{mg} / \mathrm{l}$, Ca from 1,000 mg/l -2,000 mg/l and $\mathrm{Mg}$ from $250 \mathrm{mg} / \mathrm{l}-350 \mathrm{mg} / \mathrm{l}$. There are many research journals that examine the content of palm oil waste, all of which state that palm oil waste contains macro elements needed by plants to grow and develop. Therefore, solid and liquid waste from palm oil mills can be used as organic fertilizer. Literature studies or literature studies are carried out from relevant and scientifically accountable sources so that they get valid data and become the basis of a new research. The conclusion of this study is that compost and organic liquid fertilizer from palm oil waste contains the nutrients needed for plant growth, including agarwood plants which are currently in a rare status.
\end{abstract}

Keywords: agarwood, palm oil waste liquid fertilizer, palm oil waste compost

\section{How to Cite}

Iriyawati,. Hening Widowati, Agus Sutanto. 2022. Kompos dan Pupuk Cair Limbah Sawit untuk Nutrisi Tanaman Gaharu (Aquilaria malaccensis). BIOLOVA 3(1). 38-45. 
Salah satu komoditas yang sangat menjanjikan dalam dunia industri adalah minyak goreng, maka sawit sebagai tumbuhan penghasil CPO banyak sekali dikembangkan di Indonesia. Selain sebagai penghasil CPO sawit juga memiliki peran atau manfaat lain seperti bahan pembuat syampo, margarin, detergen, produk kosmetik, sabun, lipstick, biskuit, krimer, susu, coklat, formula bayi, roti dan lain sebagainya. Hasil samping dari pengolahan berbagai produk tersebut dihasilkan limbah yang jika tidak ditangani secara serius dan tepat guna dapat menimbulkan masalah bagi lingkungan. Pada dasarnya limbah pabrik sawit dapat didegradasi oleh bakteri indigen yang terdapat di lingkungan limbah, namun hal ini berlangsung dalam waktu yang relatif lama sedang proses produksi pabrik sawit berlangsung setiap hari dan juga menghasilkan limbah setiap harinya. Jika tidak ditangani maka limbah dapat menumpuk dan menimbulkan permasalahan yang sangat serius bagi lingkungan. Terutama limbah cair sawit mengandung zat pencemar yang sangat tinggi dengan total suspended solid terkecil $5473 \mathrm{mg} / \mathrm{L}$ dan ini dapat sangat mencemari lingkungan perairan sekitar (Syamriati, 2021). Sementara limbah padat yang berupa tandan kososng kelapa sawit masih memiliki sedikit kandungan minyak sehingga dapat berpotensi menimbulkan percikan api dan jika musim penghujan maka tumpukan TKKS dapat menghasilkan cairan yang berbahaya bagi lingkungan sekitar (Nikmatin, 2020). Oleh karena itu perlu adanya pengolahan limbah pabrik sawit secara tepat. Untuk memenuhi persyaratan teknis pengolahan limbah maka tahapantahapan pengolahan limbah perlu dilakukan antara lain yaitu reduction, collection, storage, transportation, reuse/recycling, treatmen dan atau disposal. Berkaitan dengan perlakuan/ treatment limbah dapat diolah secara kimia maupun secara biologi yaitu dengan memanfaatkan mikroorganisme sehingga limbah aman bagi lingkungan.

Menurut Warsito (2016) bahwa tandan dari buah kelapa sawit yang sudah kososng dapat dimanfaatkan sebagai bahan untuk membuat pupuk organik. Hasil analisis kadar $\mathrm{N}$ dan $\mathrm{P}$ diperoleh rerata dalam persen (\%) yaitu $2,033 \%$ untuk nilai rata-rata kadar nitrogen $(\mathrm{N})$ dan $0,107 \%$ untuk nilai rata-rata kadar posforus (P). Sedangkan 36,66\% kadar abu dan 47,53\% kadar air. Sesuai dengan SNI 19-7030-2004 mengenai syarat mutu kompos dari sampah organik maka diperoleh kesimpulan bagwa limbah sawit dapat dijadikan bahan baku pembuatan pupuk organik. Dalam Bakri et al (2017) ciri limbah dari pabrik kelapa sawit adalah sebagai berikut: BOD $20.000 \mathrm{mg} / \mathrm{l} \mathrm{s.d.} 60.000 \mathrm{mg} / \mathrm{l}, \mathrm{pH}$ 4.06.0, s.d, COD $40.000 \mathrm{mg} / \mathrm{l}$ s.d.12.000 $\mathrm{mg} / \mathrm{l}, \mathrm{N} 500 \mathrm{mg} / \mathrm{l} \mathrm{s.d} 900 \mathrm{mg} / \mathrm{l}, \mathrm{P}$ dari $90 \mathrm{mg} / \mathrm{l}$ to $140 \mathrm{mg} / \mathrm{l}, \mathrm{K}$ dari $260 \mathrm{mg} / \mathrm{l}$ sampai $400 \mathrm{mg} / \mathrm{l}$, Ca dari $1.000 \mathrm{mg} / \mathrm{l}$ sampai $2.000 \mathrm{mg} / \mathrm{l}$ dan $\mathrm{Mg}$ dari 250 $\mathrm{mg} / \mathrm{l}$ sampai $350 \mathrm{mg} / \mathrm{l}$. Hal ini memenuhi persyaratan teknis minimal pupuk organik padat dan pupuk cair organik yang peraturan menteri pertanian nomor 70/permentan/sr.140/10/2011. Oleh karna itu limbah padat dapat dimanfaatkan sebagai kompos sedang limbah cair dapat dimanfaatkan sebagai pupuk cair yang berguna untuk meningkatkan laju pertumbuhan tanaman. Kompos TKKS dan POC LCPKS memiliki kandungan unsur N, $\mathrm{P}$ dan $\mathrm{K}$ yang cukup tinggi (Danial, $\mathrm{E}$ dkk : 2018) dan hal ini selaras dengan hasil penelitian yang dilakukan oleh Heriyanto (2015), bahwa dengan pemberian pupuk kompos TKKS $75 \%$ $+25 \%$ top soil menunjukkan 
perlakuan yang mampu meningkatkan pertambahan tanaman .

\section{Sejak $1984 \quad$ CITES}

(Convention on International in Trade

Endangered Species of Fauna and

Flora) menetapkan bahwa tanaman gaharu sebagai tanaman langka karnanya perlu dibudidayakan. Tidak selalu berbuah di sepanjang tahun serta memiliki biji yang tidak dapat disimpan dalam waktu lama menjadi salah satu penyebab kelangkaan pohon tersebut (Situmorang, 2000). Maka perlu upaya untuk mengatasinya yaitu dengan perbanyakan bibit tanaman. dan perbanyakan secara vegetatif dapat menjadi solusi untuk perbanyakan tanaman yaitu dengan stek yang merupakan suatu perlakuan pemisahan, pemotongan beberapa bagian tanaman seperti bagian akar, batang, daun maupun tunas dengan tujuan agar bagian bagian itu membentuk akar. Stek pucuk merupakan cara perbanyakan yang dilakukan dengan cara menumbuhkan tunas-tunas aksilar pada media tumbuh hingga tunas-tunas tersebut mampu membentuk akar-akar baru (Wudianto dalam Nababan, 2009). Stek pucuk juga dapat diartikan sebagai perbanyakan tanaman dengan menggunakan bagian pucuk yang masih muda (juvenil) yang diambil dari stock plant yang berada pada persemaian (Basiang dalam Nababan, 2009). Menurut Rochiman dan Harjadi (dalam Firmansyah, 2007) bahan stek yang berumur satu tahun biasanya baik untuk digunakan sebagai indukan stek pucuk. Bahan stek dari tanaman muda lebih cepat berakar bila dibandingkan dengan tanaman yang sudah dewasa. Hal ini dikarenakan bagian tanaman yang masih muda sel sel nya masih meristematic, masih aktif mengalami pembelahan sehingga kemampuan membentuk akarpun semakin baik. semakin dewasa suatu jaringan maka kemampuan berakar semakin menurun. Hal ini disebabkan karena berkurangnya senyawa fenol yang berfungsi sebagai kofaktor auksin, sehingga kemampuan auksin untuk menstimulasi munculnya akar juga berkurang (Moko, dalam Firmansyah, 2007).

Sumarna (2012) menyatakan bahwa dalam perbanyakan gaharu diperlukan unsur hara makro dan mikro. Untuk meningkatkan pertumbuhan vegetative tumbuhan gaharu dapat dilakukan penyemprotan unsur hara ke bagian daun tanaman. Hardjowigeno (2007) menyatakan bahwa kandungan unsur hara makro dan mikro yang diperlukan tanaman untuk pertumbuhan vegetatif adalah $\mathrm{N}, \mathrm{P}, \mathrm{K}$ dan unsure mikro lainnya. Hal ini bersesuaian dengan pernyataan dari dinas pangan, pertanian dan perikanan bahwa unsur hara makro yang diperlukan untuk pertumbuhan tanaman adalah $\mathrm{N}, \mathrm{P}, \mathrm{K}, \mathrm{S}, \mathrm{Ca}, \mathrm{Mg}$, sedangkan unsur hara mikro yang di perlukan untuk pertumbuhan tanaman adalah $\mathrm{Cl}, \mathrm{Fe}, \mathrm{Mn}, \mathrm{Cu}, \mathrm{Zn}, \mathrm{B}$ dan $\mathrm{Mo}$. Gaharu atau Agarwood mampu menghasilkan metaolit sekunder berupa resin/ damar yang kaya akan manfaat. Metode komposting mampu memberikan pengaruh dalam meningkatkan pertumbuhan bibit gaharu (Aquilaria spp.) Heriyanto (2015). Hal ini bersesuaian dengan hasil penelitian yang dilakukan oleh Azwar (2020) dengan hasil bahwa semua parameter memperlihatkan nilai signifikan pada perlakuan dengan $90 \%$ limbah sawit, semakin banyak penambahan limbah lumpur kering kelapa sawit maka semakin tinggi nilai pertumbuhan bibit gaharu yang akan diperoleh.

Menurut Heriyanto (2015:2) juga melakukan penelitian dan memperoleh kesimpulan bahwa pemberian kompos tandan kosong kelapa sawit mampu memberikan pengaruh positif untuk meningkatkan 
pertumbuhan gaharu. Pemberian pupuk kompos TKKS $75 \%+25 \%$ top soil menunjukkan perlakuan yang mampu meningkatkan pertambahan tinggi maksimum bibit yaitu $5,080 \mathrm{~cm}$, berat kering tanaman maksimum 2,034 g dan diameter maksimum $0,151 \mathrm{~mm}$,

Telah dilakukan pembuatan pupuk kompos serta pupuk cair limbah sawit oleh mahasiswa Universitas Muhammadiyah Metro dimulai dari pembuatan starter/biang berupa biakan konsorsia bakteri Limbah Cair Nanas (LCN). Konsorsia bakeri indigen LCN memiliki potensi sebagai pengurai/dekomposer dan mampu memulihkan limbah sehingga tidak mencemari lingkungan (Sutanto et al, 2020). Kemudian dilanjutkan dengan proses fermentasi pada tandan kosong kelapa sawit dan limbah cair kelapa sawit dan dilakukan pengamatan terhadap $\mathrm{pH}$, kelembaban serta suhu selama 30 hari untuk pupuk cair organik limbah sawit dan 45 hari untuk pupuk kompos limbah sawit. Setelah itu dilakukan uji kandungan pupuk baik cair ataupun kompos yang dilakukan di Laboratorium Kimia Universitas Muhammadiyah Malang terhadap produk yang dihasilkan dan dari analisis uji fungsional sampel pupuk hayati majemuk sebagai berikut:

Tabel 1. analisis uji fungsional sampel pupuk hayati majemuk

\begin{tabular}{lll}
\hline $\begin{array}{l}\text { Uji } \\
\text { fungsional }\end{array}$ & Hasil & Keterangan \\
\hline Penambat N & Postif & $\begin{array}{l}\text { Adanya bakteri } \\
\text { Nitrobacter }\end{array}$ \\
\hline Pelarut P & Postif & $\begin{array}{l}\text { Adanya bakteri } \\
\text { mycobacterium } \\
\text { spp dan } \\
\text { pseudomanas sp }\end{array}$ \\
\hline Pelarut & Postif & $\begin{array}{l}\text { Adanya baktetri } \\
\text { unsur hara }\end{array}$ \\
lain & & $\begin{array}{l}\text { Mesorhizobium } \\
\text { sp, Streptomyces }\end{array}$ \\
\hline $\begin{array}{l}\text { Pembentuk } \\
\text { bintil akar }\end{array}$ & Postif & $\begin{array}{l}\text { Adanya baktetri } \\
\text { Mesorhizobium }\end{array}$ \\
& & sp \\
\hline
\end{tabular}

Dengan demikian dapat disimpulkan bahwa kompos limbah sawit mengandung $\mathrm{Zn}$, $\mathrm{P}$ pelarut unsur hara lain dan pembentuk bintil akar.

Hasil analisis kimia sampel pupuk kompos campuran yang pengujiannya dilakukan di laboratorium kimia universitas Muhammadiyah malang diperoleh hasil sebagai berikut:

Tabel 2. Hasil Analisis Kimia Sampel Pupuk Kompos Campuran

\begin{tabular}{|c|c|c|}
\hline No & $\begin{array}{l}\text { Parameter- } \\
\text { Satuan } \\
\end{array}$ & Mutu \\
\hline 1 & Air $(\%)$ & 14,697 \\
\hline 2 & C organic $(\%)$ & 45,699 \\
\hline 3 & $\begin{array}{l}\text { Bahan Organik } \\
(\%)\end{array}$ & 78,791 \\
\hline 4 & N Total $(\%)$ & 3,394 \\
\hline 5 & Rasio C/N & 13,466 \\
\hline 6 & $\mathrm{P}_{2} \mathrm{O}_{5}$ Total & 2,330 \\
\hline 7 & $\mathrm{~K}_{2} \mathrm{O}$ Total & 3,466 \\
\hline 8 & $\mathrm{Fe}(\mathrm{mg} / 1000 \mathrm{~g})$ & 7754,119 \\
\hline 9 & $\mathrm{Zn}(\mathrm{mg} / 1000 \mathrm{~g})$ & 1011995 \\
\hline 10 & $\mathrm{pH}\left(\mathrm{H}_{2} \mathrm{O}\right)$ & 6,13 \\
\hline 11 & Mikrobiologi & \\
\hline 12 & E coli $(\mathrm{APM} / \mathrm{g})$ & 74 \\
\hline 13 & $\begin{array}{l}\text { Salmonella } \\
\text { (kualitatif) }\end{array}$ & Positif \\
\hline \multirow[t]{5}{*}{14} & $\begin{array}{l}\text { Salmonella } \\
(\mathrm{kol} / \mathrm{g})\end{array}$ & $1,992 \times 10^{1}$ \\
\hline & Kuantitatif & \\
\hline & Genus Mikroba & \\
\hline & Fungsional & \\
\hline & Jamur & \\
\hline 15 & $\begin{array}{l}\text { Alternaria } \quad s p p \\
(\mathrm{cfu} / \mathrm{g})\end{array}$ & $3,857 \times 10^{6}$ \\
\hline 16 & $\begin{array}{l}\text { Cladosporina } \\
\text { spp (cfu/g) }\end{array}$ & $5,979 \times 10^{6}$ \\
\hline 17 & $\begin{array}{l}\text { Choniophora } \\
\text { spp (cfu/g) }\end{array}$ & $5,298 \times 10^{6}$ \\
\hline 18 & $\begin{array}{l}\text { Fibroporia spp } \\
(\mathrm{cfu} / \mathrm{g})\end{array}$ & $8,179 \times 10^{6}$ \\
\hline 19 & Mucor $(\mathrm{cfu} / \mathrm{g})$ & $6,083 \times 10^{5}$ \\
\hline \multirow[t]{2}{*}{20} & $\begin{array}{l}\text { Penicillium spp } \\
(\mathrm{cfu} / \mathrm{g})\end{array}$ & $2,660 \times 10^{5}$ \\
\hline & Bakteri & \\
\hline 21 & $\begin{array}{l}\text { Achromobacter } \\
\operatorname{spp}(\mathrm{cfu} / \mathrm{g})\end{array}$ & $7,141 \times 10^{6}$ \\
\hline 22 & $\begin{array}{l}\text { Azhorizobium } \\
\text { spp (cfu/g) }\end{array}$ & $8,423 \times 10^{6}$ \\
\hline 23 & $\begin{array}{l}\text { Azotobacter spp } \\
(\mathrm{cfu} / \mathrm{g})\end{array}$ & $5,010 \times 10^{6}$ \\
\hline 25 & $\begin{array}{l}\text { Azotomonas spp } \\
(\mathrm{cfu} / \mathrm{g})\end{array}$ & $4,516 \times 10^{6}$ \\
\hline 26 & Bacillus $\quad$ spp & $2,854 \times 10^{6}$ \\
\hline
\end{tabular}




\begin{tabular}{|c|c|c|}
\hline & $(\mathrm{cfu} / \mathrm{g})$ & \\
\hline 27 & $\begin{array}{l}\text { Clostridium spp } \\
(\mathrm{cfu} / \mathrm{g})\end{array}$ & $2,685 \times 10^{6}$ \\
\hline 28 & $\begin{array}{l}\text { Enterobacter spp } \\
(\mathrm{cfu} / \mathrm{g})\end{array}$ & $4,436 \times 10^{6}$ \\
\hline 29 & $\begin{array}{l}\text { Flavobacterium } \\
\text { spp }(\mathrm{cfu} / \mathrm{g})\end{array}$ & $7,545 \times 10^{6}$ \\
\hline 30 & $\begin{array}{l}\text { Mesorhizobium } \\
\text { spp }(\mathrm{cfu} / \mathrm{g})\end{array}$ & $4,860 \times 10^{6}$ \\
\hline 31 & $\begin{array}{l}\text { Mycobacterium } \\
\text { spp }(\mathrm{cfu} / \mathrm{g})\end{array}$ & $4,261 \times 10^{6}$ \\
\hline 32 & $\begin{array}{l}\text { Nitrobacter } \\
(\mathrm{cfu} / \mathrm{g})\end{array}$ & $3,358 \times 10^{6}$ \\
\hline 33 & $\begin{array}{l}\text { Nitrosococcus } \\
\text { (cfu/g0 }\end{array}$ & $4,965 \times 10^{6}$ \\
\hline 34 & $\begin{array}{l}\text { Nitrosomonas } \\
(\mathrm{cfu} / \mathrm{g})\end{array}$ & $4,780 \times 10^{6}$ \\
\hline 35 & $\begin{array}{l}\text { Pseudomonas } \\
\text { spp (cfu/g) }\end{array}$ & $3,912 \times 10^{6}$ \\
\hline 36 & $\begin{array}{l}\text { Rhizobium spp } \\
(\mathrm{cfu} / \mathrm{g})\end{array}$ & $8,099 \times 10^{6}$ \\
\hline \multirow[t]{2}{*}{37} & $\begin{array}{l}\text { Streptomyces } \\
\operatorname{spp}(\mathrm{cfu} / \mathrm{g})\end{array}$ & $4,261 \times 10^{6}$ \\
\hline & Logam Berat & \\
\hline 38 & As (mg/1000 g) & 0,260 \\
\hline 39 & $\mathrm{Hg}(\mathrm{mg} / 1000 \mathrm{~g})$ & 0,050 \\
\hline 40 & $\mathrm{~Pb}(\mathrm{mg} / 1000 \mathrm{~g})$ & 11,423 \\
\hline 41 & $\mathrm{Cd}(\mathrm{mg} / 1000 \mathrm{~g})$ & 1,549 \\
\hline 42 & $\mathrm{Cr}(\mathrm{mg} / 1000 \mathrm{~g})$ & 28,945 \\
\hline 43 & Ni (mg/1000 g) & 18,724 \\
\hline 44 & $\begin{array}{l}\text { Ukuran Butiran } \\
2-7,5 \mathrm{~mm}(\%)\end{array}$ & 86,183 \\
\hline 45 & $\begin{array}{l}\text { Bahan Ikutan } \\
(\%)\end{array}$ & 0,548 \\
\hline
\end{tabular}

Hal ini memenuhi persyaratan teknis minimal pupuk organik padat dan pupuk cair organik yang peraturan menteri pertanian nomor 70/permentan/sr .140/10/2011. Oleh karna itu limbah padat dapat dimanfaatkan sebagai kompos sedang limbah cair dapat dimanfaatkan sebagai pupuk cair yang berguna untuk meningkatkan laju pertumbuhan tanaman. hal tersebut mengacu pada persyaratan teknis minimal pupuk organik padat dan pupuk cair organik. Berikut tabel 2. Persyaratan teknis minimal pupuk organic padat.

Table 2. Persyaratan Teknis Minimal Pupuk Organik Padat

\begin{tabular}{|c|c|c|c|c|c|c|}
\hline \multirow[t]{3}{*}{ No } & \multirow[t]{3}{*}{ PARAMETER } & \multirow{3}{*}{$\begin{array}{l}\text { SA } \\
\text { TU } \\
\text { AN }\end{array}$} & \multicolumn{4}{|c|}{ STANDAR MUTU } \\
\hline & & & \multicolumn{2}{|c|}{ Granul/Pelet } & \multicolumn{2}{|c|}{ Remah/Curah } \\
\hline & & & Murni & $\begin{array}{l}\text { Diper } \\
\text { kaya }\end{array}$ & $\begin{array}{l}\text { Mu } \\
\text { rni }\end{array}$ & $\begin{array}{c}\text { Diperk } \\
\text { aya }\end{array}$ \\
\hline
\end{tabular}

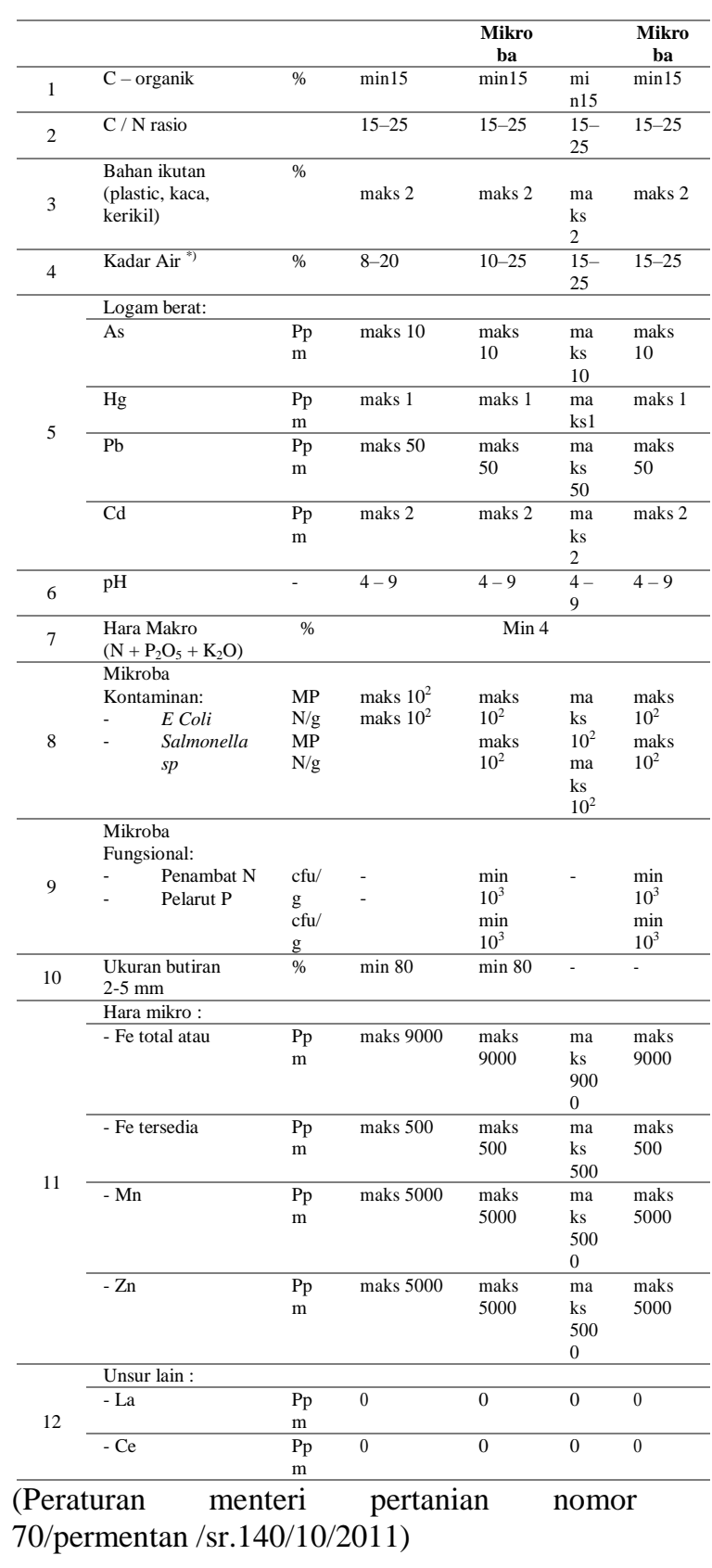

METODE

metode yang digunakan dalam penelitia ini adalah metode penelitian studi kepustakaan/kajian pustaka yang berisi teori-teori yang relevan dengan masalah penelitian dalam hal ini limbah sawit sebagai pupuk organik dan pengaruhnya terhadap pertumbuhan tanaman. Studi pustaka ini membangun dasar teori/konsep konsep yang menjadi dasar dalam penelitian. dilakukan kajian teori dengan menggunakan berbagai literatur yang berasal dari berbagai sumber seperti artikel artikel ilmiah 
yang sudah diterbitkan atau dipublish di jurnal jurnal ilmiah dan bisa dipertanggungjawabkan kebenarannya Adapun masalah pada penelitian ini adalah limbah sawit yang menumpuk tanpa adanya pemanfaatan yang optimal sehingga dapat mengganggu keseimbangan lingkungan, belum adanya studi pustaka mengenai berbagai kandungan mineral yang ada pada limbah sawit yang dapat meningkatkan pertumbuhan tanaman gaharu"

\section{HASIL}

Dari hasil kajian Pustaka ditemukan beberapa hal mengenai kareakteristik serta kandungan dari limbah sawit. Karakteristik limbah dari pabrik kelapa sawit adalah sebagai berikut: $\mathrm{pH}$ 4.0-6.0, dengan BOD $20.000 \mathrm{mg} / \mathrm{l}$ s.d $60.000 \mathrm{mg} / \mathrm{l}$, COD $40.000 \mathrm{mg} / \mathrm{l}$ s.d. $12.000 \mathrm{mg} / \mathrm{l}, \mathrm{N}$ $500 \mathrm{mg} / \mathrm{l} \mathrm{s.d} 900 \mathrm{mg} / \mathrm{l}, \mathrm{P}$ dari $90 \mathrm{mg} / \mathrm{l}$ s.d.140 mg/l, K dari $260 \mathrm{mg} / \mathrm{l}$ sampai $400 \mathrm{mg} / \mathrm{l}$, Ca dari $1.000 \mathrm{mg} / \mathrm{l}$ sampai $2.000 \mathrm{mg} / \mathrm{l}$ dan $\mathrm{Mg}$ dari $250 \mathrm{mg} / \mathrm{l}$ sampai $350 \mathrm{mg} / \mathrm{l}$, Bakri et al (2017). Hal ini bersesuaian dengan hasil penelitian yang dilakukan oleh Warsito (2016) yang memperoleh data bahwa Limbah tandan kosong kelapa sawit (TKKS) dapat dimanfaatkan sebagai bahan pembuatan pupuk organik. Analisis kadar nitrogen $(\mathrm{N})$ dan posforus $(\mathrm{P})$ yang diperoleh dari pupuk organik limbah TKKS diperoleh nilai rata-rata dalam persen $(\%)$, rata-rata kadar nitrogen $(\mathrm{N})$ yaitu sebesar $2,033 \%$ dan nilai rata-rata kadar posforus (P) sebesar 0,107\%. Sedangkan kadar abu sebanyak $36,66 \%$ dan kadar air sebanyak $47,53 \%$. Sesuai dengan SNI 19-70302004 syarat mutu kompos dari sampah organik maka hasil penelitian ini menunjukkan bahwa limbah TKKS dapat digunakan sebagai bahan baku pembuatan pupuk organik. Hardjowigeno (2015) menyatakan bahwa kandungan unsur hara makro dan mikro yang diperlukan tanaman untuk pertumbuhan vegetatif adalah $\mathrm{N}, \mathrm{P}, \mathrm{K}$ dan unsure mikro lainnya. Dan berdasarkan Sumarna (2012) menyatakan bahwa pembibitan gaharu perlu pemberiaan unsur hara makro dan mikro. Unsur makro yang diperlukan untuk pertumbuhan tanaman antara lain $\mathrm{N}, \mathrm{P}, \mathrm{K}, \mathrm{S}, \mathrm{Ca}$, $\mathrm{Mg}$ dan unsure mikro antara lain $\mathrm{Cl}$, $\mathrm{Fe}, \mathrm{Mn}, \mathrm{Cu}, \mathrm{Zn}, \mathrm{B}$ serta Mo. Heriyanto (2015) menyimpulkan bahwa semakin banyak penambahan limbah lumpur kering kelapa sawit maka semakin tinggi nilai pertumbuhan bibit gaharu yang akan diperoleh.

\section{PEMBAHASAN}

Tumbuhan

Gaharu memerlukan tumbuhan yang dalam masa pertumbuhan awal memerlukan naungan serta memerlukan unsur hara terutama yang mengandung Nitrogen $(\mathrm{N})$, Fosfor (P) dan Kalium (K), hal ini terbukti dari hasil penelitian yang telah dilakukan oleh Millang S, Bachtiar B dan Makmur A (2011) yang menyatakan bahwa pemberian NPK berpengaruh nyata terhadap pertambahan tinggi tanaman. Kompos limbah sawit merupakan hasil fermentasi tandan kosong kelapa sawit oleh bakteri pendegradasi sehingga memiliki kandungan unsur hara baik makro maupun mikro yang diperlukan oleh tumbuhan. Seperti halnya dalam Bakri et al (2017) limbah sawit memiliki karakteristik antara lain $\mathrm{N}$ $500 \mathrm{mg} / \mathrm{l} \mathrm{s.d} 900 \mathrm{mg} / \mathrm{l}, \mathrm{P}$ dari $90 \mathrm{mg} / \mathrm{l}$ s.d.140 mg/l, K dari $260 \mathrm{mg} / \mathrm{l}$ sampai $400 \mathrm{mg} / \mathrm{l}$, Ca dari $1.000 \mathrm{mg} / \mathrm{l}$ sampai $2.000 \mathrm{mg} / \mathrm{l}$ dan $\mathrm{Mg}$ dari $250 \mathrm{mg} / \mathrm{l}$ sampai $350 \mathrm{mg} / \mathrm{l}$, dan penambahan limbah lumpur kering kelapa sawit dapat meningkatkan pertumbuhan gaharu karna limbah tersebut juga mengandung usur hara yang diperlukan oleh tumbuhan. Hal ini 
bersesuaian dengan Thusteven (2014) yang menyatakan bahwa nutrisi yang baik untuk pertumbuhan gaharu adalah yang mengandung unsur utama Nitrogen, pospat dan Kalium. Fungsi dari unsur Nitrogen $(\mathrm{N})$ adalah untuk penyususnan senyawa protein sederhana berupa asam amino, DNA maupun RNA, nukleotida, serta pembentukan klorofil, sehingga dengan adanya $\mathrm{N}$ maka tanaman menjadi lebih hijau, pertumbuhan tanaman semakin cepat. Pospor (P) bagi tanaman memiliki fungsi untuk transfer energi yang berguna bagi aktivitas metabolisme tanaman, sehingga pertumbuhan akar menjadi terpacu, system perakaranpun menjadi lebih baik, pembentukan titik tumbuh tanaman, pembentukan bunga serta pematangan buah/biji dapat terpacu, masa panen semakain cepat, dan daya tahan tanaman terhadap hama dan penyakit semakin meningkat. Fungsi dari unsur Kalium (K) yaitu untuk mengaktifkan kerja enzim sehingga proses metabolism dapat berjalan dengan cepat, membantu transportasi hasil asimilasi dari daun ke jaringan tanaman, proses penyerapan air dan unsur hara dari dapat terbantu. Dengan adanya unsur calsium (Ca) maka batang tanaman dapat menjadi keras, rambut rambut akar terbentuk, merangsang pembentukan biji, calsium pada batang dan daun bermanfaat untuk menetralkan senyawa atau keadaan yang tidak menguntungkan pada tanah. Sedang unsur magnesium (Mg) memiliki peran dalam ransportasi ion phospat serta untuk membentuk klorofil (zat hijau daun), lemak, karbohidrat, serta senyawa minyak yang dibutuhkan tanaman. Dari kandungan yang dimiliki oleh limbah sawit tersebut maka diduga kuat dapat berpengaruh positif terhadap pertumbuhan tanaman, dapat meningkatkan pertumbuhan stek tanaman gaharu.
Karna fungsi tersebutlah maka kompos ataupun pupuk cair organic dari limbah sawit mampu untuk meningkatkan pertumbuhan gaharu.

\section{KESIMPULAN}

Dari hasil kajian maka dapat diperoleh kesimpulan bahwa kompos dan pupuk cair organik dari limbah sawit memiliki kandungan unsur hara yang diperlukan untuk pertumbuhan tanaman termasuk tanaman gaharu yang saat ini setatusnya sebagai tumbuhan langka.

\section{SARAN}

Perlu adanya penelitian lebih lanjut mengenai metode composting limbah sawit dalam mendegradasi tanah tercemar

\section{DAFTAR RUJUKAN}

Azwar E. 2020. The Effect of Addition of Palm Oil Dry Waste Against Growth Rate of Sawi Plant (Brassica rapa) On Learning Environmental Knowledge. International Journal for Educational and Vocational Studies, 2(8), h. 731736.

Bakri, Bernas, S.M., Budianta, D., Said, M. 2017. Application of Various Concentrations of Liquid Waste from Oil Palm Mill on the Growth of Oil Palm Plant (Elaeis guinensis, Jacq).

Kne Life Sciences.kls.v2i6.1044. h. 228-237.

Danial. E. Ogari. P.A., Diana.S., Nurlaili. 2018. Pemanfaatan Kompos Tandan Kosong Kelapa Sawit dan Limbah Cair Pabrik Kelapa Sawit Terhadap Pertumbuhan Planlet Pisang Kepok Kuning Pada Tahap Aklimatisasi. Klorofil. XIII(2). h. 83-88. 
Firmansyah YV. 2007. Pembiakan vegetatif tanaman gaharu (Aquilaria crassna Pierre Ex. Lecomte) dengan stek pucuk [skripsi]. Bogor: Fakultas Kehutanan, Institut Pertanian Bogor.

Heriyanto, M. Mardhiansyah, Sulaeman, R. 2015. Pengaruh Pemberian Pupuk Kompos Tandan Kosong Kelapa Sawit Terhadap Pertumbuhan Bibit Gaharu (Aquilaria spp). Jom, 2 (2), tanpa halaman.

Hardjowigeno, S. 2015. Ilmu Tanah. Akademik Pressindo.

Millang, S, Bachtiar, B dan Makmur, A. 2011. Awal Pertumbuhan Pohon Gaharu (Gyrinops sp) Asal Nusa Tenggara Barat di Hutan Pendidikan Universitas Hasanudin. Jurnal Hutan dan Masyarakat. 6(2). h. 117-123.

Nababan, D. 2009. Penggunaan Hormon IBA terhadap Pertumbuhan Stek Ekaliptus Klon IND 48. Departemen Kehutanan. Hasil Penelitian. Fakultas Pertanian USU, Medan. USU Repository.

Nikamatin, S. 2020. Dosen IPB University Berikan Solusi Pengolahan Limbah Tandan Kosong Kelapa Sawit. https://www.ipb.ac.id/news/inde x/2020/01/dosen-ipb-universityberikan-solusi-pengolahanlimbah-tandan-kosong-kelapasawit/ca3335cb5012d56f4d5f40 e74f630f06. 07 Februari 2022 (02:10).

Peraturan menteri pertanian nomor 70/ permentan/sr.140/10/2011 tentang pupuk organik, pupuk hayati dan pembenah tanah nomor70/permentan/sr.140/10/2 011
Sumarno, Y. 2012. Budidaya Jenis Pohon Penghasil Gaharu. Badan Penelitian dan Pengembangan Kehutanan Pusat Litbang Produktifitas Hutan. Bogor.

Sutanto, A., Widowati, H., Achyani, Thresia, F., Hendri N., Rifai. M.R. and Yulistiana E. 2020. The Effectiveness of Pumakkal Organic Waste Bioremediator. International Journal of Advanced Science and Technology. 29(7). h. 132143.

Syamriati. 2021. Kajian Dampak Limbah Kelapa Sawit Terhadap Kualitas Perairan Sungai Budong-Budong Sulawesi Barat. Jurnal Ecosolum. 10(1). h. 1-25.

Thusteven, S.N., 2014. Budidaya Pohon Penghasil Gaharu (Aquilaria malaccensis) di Kenagarian Pilubang, Kecamatan Harau, Provinsi Sumatra Barat. Jurnal Nasional Ecopedon 1 (1). h. 1-4.

Warsito, J., Sabang, S.M., Mustapa, K. 2016. Pembuatan Pupuk Organik dari Limbah Tandan Kosong Kelapa Sawit. J. Akad. Kim. 5(1). h. 8-15. 